\title{
Reproductive performance of Palmistichus elaeisis Delvare and LaSalle (Hymenoptera: Eulophidae) with previously refrigerated pupae of Bombyx mori L. (Lepidoptera: Bombycidae)
}

\author{
Pereira, FF. ${ }^{\mathrm{a}}$ Zanuncio, JC. ${ }^{\text {a* }}$, Serrão, JE. ${ }^{\mathrm{b}}$, Pastori, PL. ${ }^{\mathrm{c}}$ and Ramalho, F.S. ${ }^{\mathrm{d}}$ \\ aDepartamento de Biologia Animal, Universidade Federal de Viçosa - UFV, \\ Av. P.H. Rolfs, Campus Universitário, CEP 36570-000, Viçosa, MG, Brazil

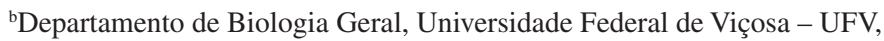 \\ Av. P.H. Rolfs, Campus Universitário, CEP 36570-000, Viçosa, MG, Brazil \\ 'Programa de Pós-graduação, Departamento de Fitotecnia, Universidade Federal de Viçosa - UFV, \\ Av. P.H. Rolfs, Campus Universitário, CEP 36570-000, Viçosa, MG, Brazil \\ 'Unidade de Controle Biológico, Embrapa Algodão, \\ CP 174, CEP 58107-720, Campina Grande, PB, Brazil \\ *e-mail: zanuncio@ufv.br
}

Received September 10, 2007 - Accepted April 4, 2008 - Distributed August 31, 2009

(With 5 figures)

\begin{abstract}
The mass rearing of parasitoids represents a fundamental stage for programmes of biological control. The progeny of the parasitoid Palmistichus elaeisis Delvare and LaSalle (Hymenoptera: Eulophidae) were evaluated on previously refrigerated pupae of Bombyx mori L. (Lepidoptera: Bombycidae). Forty-eight to 72 hours-old pupae of B. mori were stored at $10^{\circ} \mathrm{C}$ for five, 10,15 or 20 days and then exposed to parasitism by P. elaeisis females. This parasitoid showed shorter duration of the life cycle when reared on pupae of $B$. mori which were previously stored at $10^{\circ} \mathrm{C}$ during 15 days. P. elaeisis parasitized $100 \%$ of the pupae of $B$. mori after storage at $10{ }^{\circ} \mathrm{C}$ during all periods with emergence of this parasitoid from 78 to $100 \%$ of these pupae. P. elaeisis had a higher number of progeny per pupa of $B$. mori stored for 15 days at $10{ }^{\circ} \mathrm{C}$. Pupae of $\mathrm{B}$. mori can be stored for 15 days at $10{ }^{\circ} \mathrm{C}$ before being used to rear P. elaeisis.
\end{abstract}

Keywords: parasitoids, mass-rearing, host, temperature.

\section{Desempenho reprodutivo de Palmistichus elaeisis (Hymenoptera: Eulophidae) em pupas refrigeradas de Bombyx mori (Lepidoptera: Bombycidae)}

\begin{abstract}
Resumo
A criação de parasitoides em larga escala representa uma etapa fundamental para programas de controle biológico. A progênie de Palmistichus elaeisis Delvare and LaSalle (Hymenoptera: Eulophidae) foi avaliada em pupas de Bombyx mori L. (Lepidoptera: Bombycidae) armazenadas em baixa temperatura. Pupas de B. mori, com 48 a 72 horas de idade, foram armazenadas a $10{ }^{\circ} \mathrm{C}$ por $5,10,15$ ou 20 dias e, posteriormente, expostas ao parasitismo por fêmeas de P. elaeisis. A duração do ciclo de vida do parasitoide foi menor em pupas de B. mori armazenadas a $10{ }^{\circ} \mathrm{C}$ durante 15 dias. O parasitismo de P. elaeisis atingiu $100 \%$ de pupas de $B$. mori após armazenamento a $10{ }^{\circ} \mathrm{C}$ em todos os períodos, com emergência de 78 a $100 \%$ desse parasitoide. A progênie por pupa de $P$. elaeisis foi maior quando pupas de B. mori foram armazenadas por 15 dias a $10^{\circ} \mathrm{C}$. Pupas de B. mori podem ser armazenadas por até 15 dias a $10^{\circ} \mathrm{C}$ e serem utilizadas em criações de P. elaeisis.
\end{abstract}

Palavras-chave: parasitoides, manejo da criação massal, hospedeiro, temperatura.

\section{Introduction}

Hymenoptera parasitoids can reduce the populations of Lepidoptera pests in eucalyptus plantations (Zanuncio et al., 1998; Bragança et al., 1998ab; Dall'Oglio et al., 2003). Palmistichus elaeisis Delvare and LaSalle (Hymenoptera: Eulophidae) was reported from pupae of Eupseudosoma involuta (Sepp) (Lepidoptera: Arctiidae) and Euselasia eucerus Hewitson (Lepidoptera: Riodinidae) (Delvare and Lasalle, 1993), Sabulodes sp. (Lepidoptera: Geometridae) (Bittencourt and Berti Filho, 1999) and Thyrinteina arnobia (Stoll) and Thyrinteina leucoceraea Rindge (Lepidoptera: Geometridae) (Pereira, 2006). This generalist polyphagous behaviour 
characterises $P$. elaeisis as a species with high potential for the biological control of Lepidoptera defoliators of eucalyptus forests.

Mass rearing facilities are important for programs of biological control. However, the lack of adequate artificial diets makes it necessary to use large numbers of preferential or alternative hosts to produce these natural enemies (Milward-de-Azevedo et al., 2004). The preservation of hosts at low temperatures for later use without losses on the reproductive caracteristics of parasitoids is important to increase the production of these agents of biological control (Thomazini and Berti-Filho, 1998; Leopold et al., 1998; Floate, 2002; Pratissoli et al., 2003; Milward-de-Azevedo et al., 2004).

The silkworm Bombyx mori L. (Lepidoptera: Bombycidae) can be reared with low costs and its pupae present high protein value and reduced metabolic activity at $10^{\circ} \mathrm{C}$ (Ito, 1978; Greiss et al., 2003; Wang-Dun et al., 2004). B. mori can be an alternative host for pupa endoparasitoids and, for this reason, the objective of this study was to evaluate the progeny of $P$. elaeisis reared on pupae of this host after storage at $10{ }^{\circ} \mathrm{C}$ during different periods.

\section{Material and Methods}

The experiment was developed in the Laboratory of Biological Control of the Animal Biology Department of the Federal University of Viçosa (UFV) in the Municipality of Viçosa, Minas Gerais State, Brazil, with the following stages:

\subsection{Rearing of B. mori}

First instar larvae of B. mori were supplied by the Sericiculture Laboratory of the Animal Biology Department (UFV). They were reared in plastic trays $(39.3 \times 59.5 \times 7.0 \mathrm{~cm})$ with mulberry leaves supplied daily. The pupae of $B$. mori obtained were transferred to plastic trays $(28.3 \times 36.0 \times 7.0 \mathrm{~cm})$ and maintained at $25 \pm 1{ }^{\circ} \mathrm{C}, 70 \pm 10 \%$ relative humidity and photo phase of 14 hours.

\subsection{Rearing the parasitoid}

Adults of $P$. elaeisis collected in Viçosa, Minas Gerais State, Brazil (20 $45^{\prime} \mathrm{S}$ and $\left.42^{\circ} 51^{\prime} \mathrm{W}, 651 \mathrm{~m}\right)$ and reared in the Laboratory of Biological Control of the Department of Animal Biology of the Federal University of Viçosa (UFV) were maintained in glass tubes $(14.0 \times 2.2 \mathrm{~cm})$ closed with a cotton wad and with honey droplets in its interior as food for them. Forty-eight to 72 hours old pupae of $B$. mori were removed from the cocoons and exposed to parasitism by $P$. elaeisis females for 24 hours at $25 \pm 2{ }^{\circ} \mathrm{C}, 70 \pm 10 \%$ of relative humidity and photo phase of 14 hours to maintain the $P$. elaeisis population.

\subsection{Storage of B. mori pupae at low temperature and its effect on the biology of P. elaeisis.}

Forty-eight to 72 hours-old pupae of $B$. mori were stored at $10{ }^{\circ} \mathrm{C}$ for $5,10,15$ or 20 days and the control was represented by pupae of this species without storage at low temperature. Each pupa was exposed to the parasitism by 45 P. elaeisis females into glass tubes $(14.0 \times 2.2 \mathrm{~cm})$ for 24 hours at $25 \pm 2{ }^{\circ} \mathrm{C}, 70 \pm 10 \%$ relative humidity and a photo phase of 14 hours. These females were removed from the tubes at the end of this period. The duration of the life cycle (egg-adult); the percentage of parasitism (without the natural mortality of the host) (Abbott (1925); the percentage of emergence of the progeny; the number of parasitoids emerged per pupa of $B$. mori; the longevity of the descendants and the sex ratio (calculated with the equation Rs = number of females/number of adults) were obtained. The sex of the parasitoids emerged was determined based on the morphological characteristics of their antenna and abdomen (Delvare and Lasalle, 1993).

\subsection{Statistical methods}

The treatments were represented by pupae of $B$. mori after storage during zero (control), 5, 10, 15 or 20 days. A total of ten replications was used in an entirely casualised design, each one represented by one pupa of $B$. mori. The data of the duration of the life cycle, the number of individuals of $P$. elaeisis emerged per pupa of B. mori, the sex ratio and the longevity of females of this parasitoid were submitted to variance at $5 \%$ and regression analysis. The percentage of parasitism and emergence of P. elaeisis were submitted to the analysis of a generalised linear model with binomial distribution $(\mathrm{P}=0.05)$ using the R Statistical System (Ihaka and Gentleman, 1996).

\section{Results}

P. elaeisis had minimum (19 to 20 days) and maximum (27 to 31 ) duration of its life cycle (egg-adult) with pupae of $B$. mori stored at $10{ }^{\circ} \mathrm{C}$ during 15 and 20 days, respectively $\left(\mathrm{R}^{2}\right.$ Treat $=0.6756$; ANOVA, $\mathrm{F}=15.6398$; $\left.\mathrm{P}<0.001 ; \mathrm{Df}_{\text {erro }}=36\right)($ Figure 1)

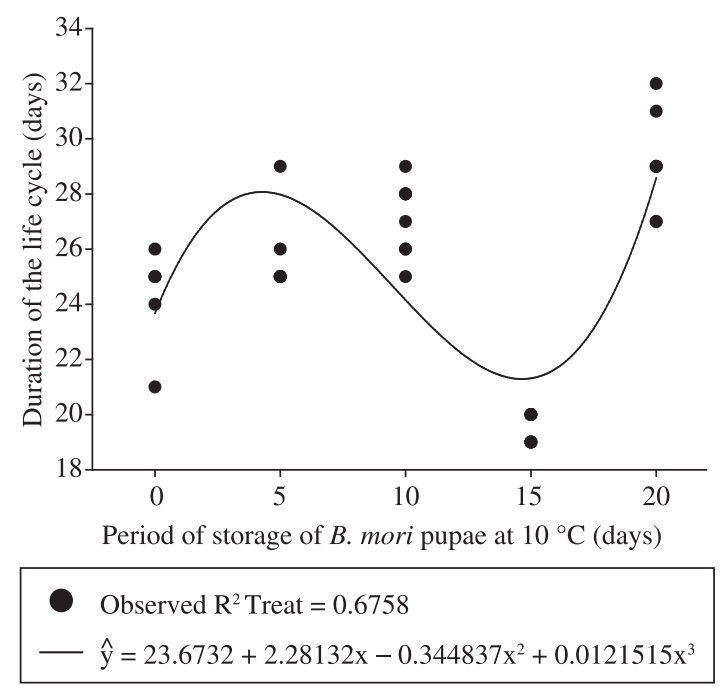

Figure 1. Duration of the life cycle (egg-adult) of P. elaeisis (Hymenoptera: Eulophidae) in pupae of B. mori (Lepidoptera: Bombycidae) after storage for zero, $5,10,15$ or 20 days at $10^{\circ} \mathrm{C}$, $70 \pm 10 \%$ relative humidity and photo phase of 14 hours. 
P. elaeisis parasitised $100 \%$ of B. mori pupae with adult emergence from 78 to $100 \%$, showing no effect of the storage periods of the pupae of this host at $10{ }^{\circ} \mathrm{C}$ $\left(\chi^{2}=32.577 ; \mathrm{P}=0.116\right)$ (Figure 2).

The progeny of P. elaeisis varied from 728 to 1414 individuals per pupa of $B$. mori after storage of them during 15 days at $10{ }^{\circ} \mathrm{C}\left(\mathrm{R}^{2}\right.$ Treat $=0.7232$; ANOVA, $\left.\mathrm{F}=18.0191 ; \mathrm{P}<0.001 ; \mathrm{Df}_{\text {erro }}=36\right)$ (Figure 3$)$.

The sex rate and the longevity of females of $P$. elaeisis emerged from pupa of $B$. mori were similar for those stored during different periods at $10{ }^{\circ} \mathrm{C}$ with averages from 0.94 to $0.96(\mathrm{~F}=2.1335 ; \mathrm{P}=0.1340)$

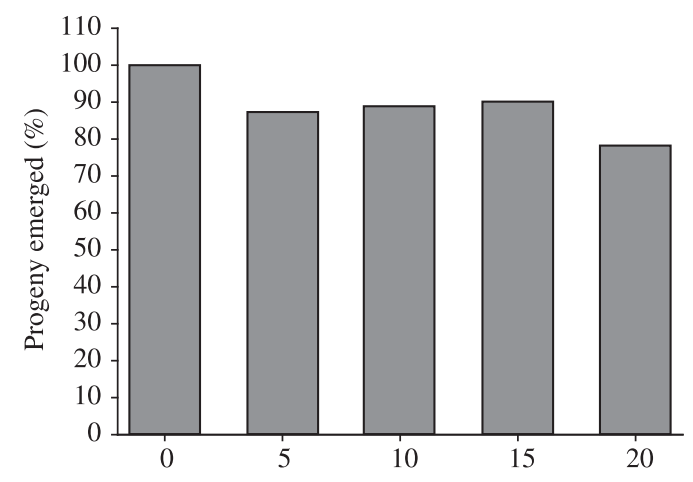

Period of storage of B. mori pupae at $10^{\circ} \mathrm{C}$ (days)

Figure 2. Percentage of pupae of B. mori (Lepidoptera: Bombycidae) with emergency of $P$. elaeisis (Hymenoptera: Eulophidae) after storage for zero, 5, 10, 15 or 20 days at $10{ }^{\circ} \mathrm{C}, 70 \pm 10 \%$ relative humidity and photo phase of 14 hours. $\left(\chi^{2}=32.577 ; \mathrm{P}=0.116\right)$.

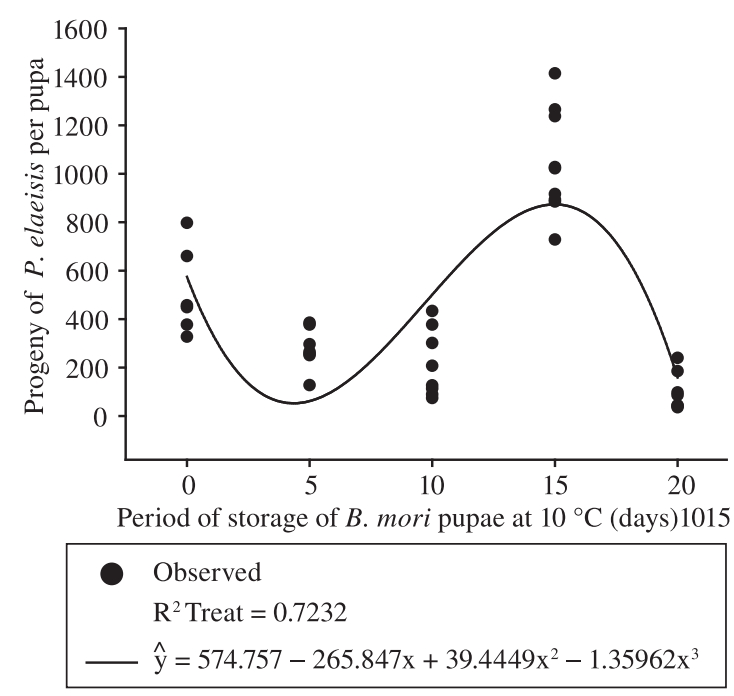

Figure 3. Progeny of $P$. elaeisis (Hymenoptera: Eulophidae) per pupae of $B$. mori (Lepidoptera: Bombycidae) after storage for zero, $5,10,15$ or 20 days at $10{ }^{\circ} \mathrm{C}, 70 \pm 10 \%$ relative humidity and photo phase of 14 hours.
(Figure 4) and 15.66 to 18.73 days (ANOVA, $F=0.0155$; $\mathrm{P}=0.9013$ ) (Figure 5), respectively.

\section{Discussion}

P. elaeisis developed in pupae of $B$. mori storage at $10{ }^{\circ} \mathrm{C}$ for different periods. The shorter duration of the life cycle of $P$. elaeisis with fresh pupae of $B$. mori in relation to those stored during 15 days at $10{ }^{\circ} \mathrm{C}$ indicates that pupae of this host are adequate for the development of $P$. elaeisis after storage at this temperature. This shows that pupae of $B$. mori maintain adequate physiological and/or nutritional conditions for the development of this parasitoid after being stored for determined period at low temperature. This can vary with the species of parasitoids and their hosts (Legner, 1979) because Muscidifurax uniraptor Kogan and Legner

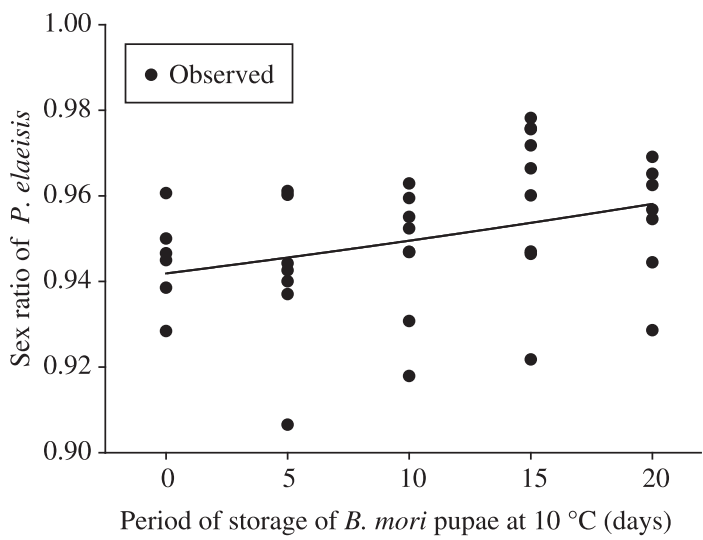

Figure 4. Sex ratio of P. elaeisis (Hymenoptera: Eulophidae) emerged from pupae of $B$. mori (Lepidoptera: Bombycidae) after storage for zero, $5,10,15$ or 20 days at $10{ }^{\circ} \mathrm{C}, 70 \pm 10 \%$ relative humidity and photo phase of 14 hours. $(\mathrm{F}=2.1335$; $\mathrm{P}=0.1340)$.

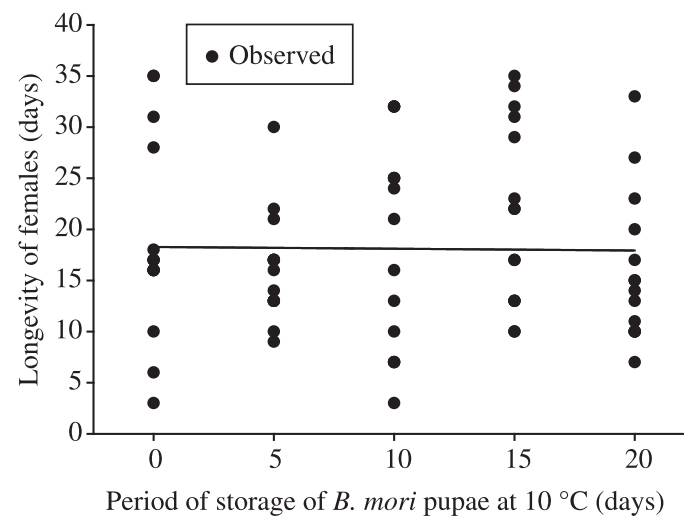

Figure 5. Longevity of P. elaeisis (Hymenoptera: Eulophidae) females emerged from pupae of B. mori (Lepidoptera: Bombycidae) after storage for zero, $5,10,15$ or 20 days at $10{ }^{\circ} \mathrm{C}, 70 \pm 10 \%$ relative humidity and photo phase of 14 hours. ( $\mathrm{F}=0.0155 ; \mathrm{P}=0.9013)$. 
(Hymenoptera: Pteromalidae) presented lower reproductive capacity with pupae of Musca domestica L. (Diptera: Muscidae), cold stored from one to two days in relation to fresh ones. However, this parasitoid had similar or higher reproduction with pupae cold stored for longer periods in relation to the control (Thomazini and Berti-Filho, 1998) such as observed for P. elaeisis with pupae of $B$. mori after storage during 15 days.

Insect pupae present immunological responses against immatures of parasitoids but they cannot maintain these defense mechanisms (encapsulation and production of toxins) active for very long due to its high metabolic cost (Schmidt et al., 2001; Schmid-Hempel, 2005). Moreover, low temperatures can, gradually, reduce the defense capacity of insect species (Duman and Horwath, 1983). This would justify the better progeny production of $P$. elaeisis from pupae of B. mori after storage at low temperature during 15 days. The longest development period of $P$. elaeisis in pupae of $B$. mori stored during 20 days shows that these pupae are less adequate for the immature of this parasitoid. This occurs because refrigeration for long periods may damage the cells of the pupae which consequently reduces its nutritional quality for parasitoids (Milward-de -Azevedo et al., 2004).

The high parasitism and emergence of individuals of $P$. elaeisis from pupae of $B$. mori after storage at $10{ }^{\circ} \mathrm{C}$ during all periods is important, showing that low temperatures constitute a strategy to preserve and to increase the availability of this host to be used at the right time to produce parasitoids in mass rearing programs (Thomazini and Berti-Filho, 1998; Leopold et al., 1998; Floate, 2002; Pratissoli et al., 2003; Milward-deAzevedo et al., 2004).

$P$. elaeisis produced progeny with pupae of $B$. mori after storage at $10{ }^{\circ} \mathrm{C}$ during all periods. However, this parasitoid showed a tendency to decreasing reproductive capacity with pupae of this host stored for five or ten days in relation to those stored for 15 days at $10^{\circ} \mathrm{C}$. This indicates that pupae of $\mathrm{B}$. mori are nutritionally more adequate and/or they present a lower defense capacity by immunological response against immatures of this parasitoid after being stored for this last period at $10{ }^{\circ} \mathrm{C}$ (Vinson and Iwantsch, 1980; Beckage, 1985). On the other hand, the lower progeny of P. elaeisis with pupae of $B$. mori after storage during 20 days can be related to morphological and physiological changes or reduced metabolism (Chapman, 1998). The impact of these changes on the progeny of parasitoids is not well-known but it may determine their susceptibility to natural enemies (Pfannenstiel et al., 1996).

$P$. elaeisis showed high sex ratios. This is important for mass rearing programs, laboratory experiments and selection of individuals to be released in the field. Thus, the predominance of females can increase the number of individuals produced in the following generation (Uçkan and Gulel, 2002; Amalin et al., 2005).

The similar longevity of females of $P$. elaeisis in pupae of B. mori stored or not is important, because the sur- vival rate is one of the requisites used for quality control in mass rearing facilities of parasitoids (Van Lenteren, 2000).

Pupae of B. mori can be stored in an acclimatised chamber $\left(10{ }^{\circ} \mathrm{C}\right)$ up to 15 days for subsequent mass production of $P$. elaeisis. The biological characteristics of this parasitoid (duration of the life cycle, percentage of parasitism and emergency, sex ratio and longevity) of $P$. elaeisis were not affected by the preservation of $B$. mori pupae at low temperatures.

\section{Conclusion}

Pupae of B. mori can be stored at $10{ }^{\circ} \mathrm{C}$ for 5,10 or 15 days but this last period can be recommended as the most adequate for mass producing $P$. elaeisis.

Acknowledgements - We thank the "Conselho Nacional de Desenvolvimento Científico e Tecnológico (CNPq)", "Coordenação de Aperfeiçoamento de Pessoal de Nível Superior (CAPES)" and "Fundação de Amparo à Pesquisa do Estado de Minas Gerais (FAPEMIG)". We are also grateful to Dr. Christer Hansson, Department of Zoology, Lund University, Sweden and Dr. Marcelo Teixeira Tavares of the Departamento de Ciências Biológicas da Universidade Federal do Espírito Santo for the identification of the parasitoid P. elaeisis.

\section{References}

ABBOTT, WS., 1925. A method of computing the effectiveness of an insecticide. Journal of Economic Entomology, vol. 18, no. 1 , p. 265-267.

AMALIN, DM., PENA, JE. and DUNCAN, RE., 2005. Effects of host age, female parasitoid age, and host plant on parasitism of Ceratogramma etiennei (Hymenoptera: Trichogrammatidae). Florida Entomologist, vol. 88, no. 1, p. 77-82.

BECKAGE, NE., 1985. Endocrine interactions between endoparasitic insects and their hosts. Annual Review of Entomology, vol. 30, p. 371-413.

BITTENCOURT, MAL. and Berti-Filho, E., 1999. Preferência de Palmistichus elaeisis por pupas de diferentes lepidópteros pragas. Scientia Agricola, vol. 56, no. 5, p. 1281-1283.

BRAGANÇA, MAL., Souza, O. and ZANUNCIO, JC., 1998a. Environmental heterogeneity as a strategy for pest management in Eucalyptus plantations. Forest Ecology and Management, vol. 102 , no. 1 , p. $9-12$.

BRAGANÇA, MAL., ZANUNCIO, JC., PICANÇO, M. and LARANJEIRO, AJ., 1998b. Effects of environmental heterogeneity on Lepidoptera and Hymenoptera populations in Eucalyptus plantations in Brazil. Forest Ecology and Management, vol. 103, no. 2-3, p. 287-292.

CHAPMAN, RF., 1998. The insects: structure and function. 4 ed. New York: Cambridge University Press. 788 p.

DALL'OGLIO, OT., ZANUNCIO, JC., FREITAS, FA. and PINTO, R., 2003. Himenópteros parasitóides coletados em povoamentos de Eucalyptus grandis e mata nativa em Ipaba, Estado de Minas Gerais. Ciência Florestal, vol. 13, no. 1, p. $123-129$.

DELVARE, G. and LASALLE, J., 1993. A new genus of Tetrastichinae (Hymenoptera: Eulophidae) from the Neotropical 
region, with the description of a new species parasitic on key pests of oil palm. Journal of Natural History, vol. 27, no. 2, p. 435-444.

DUMAN, J. and HORWATH, K., 1983. The role of hemolymph proteins in the cold tolerance of insects. Annual Review of Entomology, vol. 45, p. 261-270.

FLOATE, KD., 2002. Production of filth fly parasitoids (Hymenoptera: Pteromalidae) on fresh and on freeze-killed and stored house fly pupae. Biocontrol Science and Technology, vol. 12 , no. 5 , p. 595-603

GREISS, H., PETKOV, N., BOITCHEV, K. and PETKOV, Z., 2003. Study on improved technology for the silkworm Bombyx mori L. rearing in Egypt. II. Commercial egg production. Bulgarian Journal of Agricultural Science, vol. 9, no. 1, p. $109-112$

IHAKA, R. and GENTLEMAN, RR., 1996. A language for data analysis and graphics. Journal of Computational and Graphical Statistics, vol. 5, no. 3, p. 299-314.

ITO, T., 1978. Physiology. In TAZIMA, Y. (Ed). The silkworm: an important laboratory tool. Tokyo: Kodansha. p. 40-47.

LEGNER, EF., 1979. Reproduction of Spalangia endius, Muscidifurax raptor and M. zaraptor on fresh vs. refrigerated fly hosts. In Annals of the Entomological Society of America, vol. 72, no. 1, p. 155-157.

LEOPOLD, RA., ROJAS, RR. and ATKINSON, PW., 1998. Post pupariation cold storage of three species of flies: Increasing chilling tolerance by acclimation and recurrent recovery periods. Cryobiology, vol. 36, no. 3, p. 213-224.

MILWARD-DE-AZEVEDO, EMV., SERAFIN, I., PIRANDA, EM. and GULIAS-GOMES, CC., 2004. Desempenho reprodutivo de Nasonia vitripennis Walker (Hymenoptera: Pteromalidae) em pupas crioconservadas de Chrysomia megacephala Fabricius (Diptera: Calliphoridae): avaliação preliminar. Ciência Rural, vol. 34, no. 1, p. 207-211.

PEREIRA, FF., 2006. Desenvolvimento e técnicas de criação de Palmistichus elaeisis (Hymenoptera: Eulophidae) em hospedeiros natural e alternativo. Viçosa: Universidade Federal de Viçosa. [Tese de Doutorado].
PRATISSOLI, D., VIANNA, UR., OLIVEIRA, HN. and PEREIRA, FF., 2003. Efeito do armazenamento de ovos de Anagasta kuehniella (Lepidoptera: Pyralidae) nas características biológicas de três espécies de Trichogramma (Hymenoptera: Trichogrammatidae). Ceres, vol. 50, no. 287, p. 95-105.

PFANNENSTIEL, RS., BROWNING, HW. and SMITH JUNIOR, JW., 1996. Suitability of Mexican rice borer (Lepidoptera: Pyralidae) as a host for Pediobius furvus (Hymenoptera: Eulophidae). Environmental Entomology, vol. 25 , no. 3, p. 672-676.

SCHMID-HEMPEL, P., 2005. Evolutionary ecology of insect immune defenses. Annual Review of Entomology, vol. 50, p. $529-551$.

SCHMIDT, O., THEOPOLD, V. and STRAND, MR., 2001. Innate immunity and its evasion and suppression by Hymenoptera endoparasitoid. BioEssays, vol. 23, no. 4, p. 344-351.

THOMAZINI, MJ. and BERTI-FILHO, E., 1998. Capacidade reprodutiva de Muscidifurax uniraptor Kogan and Legner (Hymenoptera: Pteromalidae) em pupas refrigeradas de Musca domestica (Diptera: Muscidae). Arquivos do Instituto Biológico, vol. 65 , no. 1 , p. $17-20$.

UÇKAN, F. and GULEL, A., 2002. Age-related fecundity and sex ratio variation in Apanteles galleriae (Braconidae) and host effect on fecundity and sex ratio of its hyperparasitoid Dibrachys boarmiae (Hym., Pteromalidae). Journal of Applied Entomology, vol. 126, no. 10, p. 534-537.

Van LENTEREM, JC., 2000. Controle de qualidade de agentes de controle biológico produzidos massalmente: conhecimento, desenvolvimento e diretrizes. In BUENO, VHP. (Ed.). Controle biológico de pragas: produção massal e controle de qualidade. Lavras: UFLA. p. 21-40.

VINSON, SB. and IWANTSCH, GF., 1980. Host suitability for insect parasitoids. Annual Review of Entomology, vol. 25, p. $397-419$.

WANG-DUN, BAI-YAOYU. and ZHANG-CHUANXI., 2004. A review on the nutritive value of silk worm pupae and its exploitation. Entomological Knowledge, vol. 41, no. 5, p. 418-421.

ZANUNCIO, JC., MEZZOMO, JA., GUEDES, RCN. and OLIVEIRA, AC., 1998. Influence of strips of native vegetation on Lepidoptera associated with Eucalyptus cloeziana in Brazil. Forest Ecology and Management, vol. 108, no. 1, p. 85-90. 